\title{
CORRIGENDUM
}

\section{Neuroprotection after a first episode of mania: a randomized controlled maintenance trial comparing the effects of lithium and quetiapine on grey and white matter volume}

M Berk, O Dandash, R Daglas, SM Cotton, K Allott, A Fornito, C Suo, P Klauser, B Liberg, L Henry, C Macneil, M Hasty, P McGorry, Cs Pantelis and M Yücel

Translational Psychiatry (2017) 7, e1041; doi:10.1038/tp.2017.13; published online 21 February 2017

Correction to: Translational Psychiatry (2017) 7, e1011; doi:10. 1038/tp.2016.281; published online 24 January 2017

The 14th author's name was presented incorrectly. The correct listing is C Pantelis. (c) (i) This work is licensed under a Creative Commons Attribution 4.0 article are included in the article's Creative Commons license, unless indicated otherwise in the credit line; if the material is not included under the Creative Commons license, users will need to obtain permission from the license holder to reproduce the material. To view a copy of this license, visit http://creativecommons.org/licenses/ by/4.0/

(c) The Author(s) 2017 